\title{
Na zona de sacrifício, a riqueza e o lixo: aterros, lixões, minas e suas alternativas infernais
}

\author{
In the area of sacrifice, wealth and the garbage: landfills, \\ dumps, mines and their infernal alternatives
}

\section{Cleyton Gerhardt}

Brasil. Instituto de Relações Internacionais e Defesa. Cientista social pela Universidade Federal Rural do Rio de Janeiro (UFRRJ), professor e pesquisador do Instituto de Relações Internacionais e Defesa (IRID) da Universidade Federal do Rio de Janeiro. ID ORCID: https://orcid.org/0000-0001-74932458. E-mail: cleytonge@gmail.com. Colaboração: pesquisa bibliográfica, análise de dados, redação.

\section{Lair Medeiros Araújo}

Brasil. Escola Estadual Santa Tecla. Historiadora e mestra em Desenvolvimento Rural pela Universidade Federal do Rio Grande do Sul (UFRGS), professora na Escola Estadual Santa Tecla. ID ORCID: https://orcid.org/0000-0002-5840-3000.E-mail: lair.medeiros@ufrgs.br. Colaboração: pesquisa bibliográfica, pesquisa empírica, análise de dados, redação.

\section{Resumo}

$\mathrm{O}$ artigo trata de conflitos decorrentes de injustiças ambientais ligadas à mineração de rochas e implantação de um lixão/aterro sanitário na área rural de Santa Tecla, Gravataí/RS, visando analisar como se dão as relações de poder locais e a atuação de empresas e poder público na condução de ambas as atividades. A partir de um enfoque etnográfico e pesquisa documental, o estudo mostra como Santa Tecla está inserida em um contexto de produção de "zonas de sacrifício" onde, a partir da imposição de "alternativas infernais" aos moradores, mineração e deposição de lixo unem num mesmo local as duas pontas situadas mais à jusante e montante de todo processo capitalista de produção, circulação, consumo e descarte/reuso. Como resultado tem-se a baixa qualidade de vida e a produção deste rebaixamento, com a população vendo-se exposta, entre outros constrangimentos, à explosões, depreciação de imóveis, perda de produção agrícola, contaminação da água, problemas de saúde e o estigma de morar ao lado de um lixão/aterro, com seus odores e chorumes lançados no ar, terra, rios e córregos. Para quem vive do lixo (catadores), nota-se a contradição de um Estado que primeiro cria uma situação limite (lixão) para, após atrair quem vive às suas margens, atuar (com o aterro sanitário) com violência excluindo-os do usufruto de algo que ele próprio gerou, mas que agora é visto como "perigoso" justamente para quem sua ação atraiu, os quais são tratados como "invasores".

Palavras-chave: Conflitos Ambientais, Aterro/Lixão, Mineração, Zona de Sacrifício. 


\section{Abstract}

This article discusses the conflicts arising from environmental injustice related to rock mining and the implementation of a landfill in the rural area of Santa Tecla, Gravataí (RS). The aim of this study is to analyze, firstly, how local power relations and the performance of companies and public power work in the conduct of both activities; and secondly, how the local population organizes and responds to the environmental impacts generated by them. From an ethnographic approach as well as bibliographical and documentary research, the study shows how Santa Tecla is situated amidst a context of "sacrificial zones" where, based on the imposition of "infernal alternatives" to the residents, mining and depositing garbage unite the two most upstream and downstream capitalist processes of production, circulation, consumption and disposal in the same place. As a result, not only the low quality of life, but the product of this debasement, resulting in the population being exposed to the following, among other things: explosions, depreciation of real estate, loss of agricultural production, water contamination, health issues, and the stigma of living next to a dump/landfill, with its odors and slurries thrown into the air, land and rivers. A contradiction pertaining to those who rely on garbage for a living (waste pickers) is that the State, after attracting people to the general region of the landfill, first creates an extreme situation (landfill) to then act with violence and exclude them from profiting from something that the very State has generated but which is now seen as "dangerous" precisely to the people who were attracted to the region and are then treated as "invaders".

Keywords: Environmental Conflicts, Landfill/Dump, Mining, Sacrificial Zone.

\section{INTRODUÇÃO}

Injustiças ambientais ligadas a grandes obras têm sido cada vez mais objeto de análises sociológicas e antropológicas. O presente artigo aprofunda alguns desdobramentos do debate a partir do estudo envolvendo duas atividades distintas que, estruturalmente, se completam: mineração e deposição de lixo urbano. Para tanto, toma-se como universo empírico Santa Tecla, realidade com a qual os autores mantêm contato sistemático desde $2014^{1}$. Sendo parte da zona rural de Gravataí, região metropolitana de Porto Alegre, além da agricultura familiar e da Mata Atlântica (que atrai visitantes de cidades

\footnotetext{
Ver Araújo (2017).
} 
próximas e donos de sítios de lazer), a localidade abriga iniciativas danosas em termos ecológicos e dos transtornos que causam, entre elas extração de rocha basáltica e existência de um lixão/aterro sanitário.

Executadas numa mesma "zona de sacrifício", em Santa Tecla se juntam atividades que condizem com o início e o fim das complexas cadeias por trás da circulação de mercadorias: de um lado, a extração de matéria prima via mineração, base de toda produção mercantil, acumulação de capital e da própria sociedade tal como se organiza hoje; de outro, a deposição de resíduos em lixões e aterros sanitários. Por trás desta ligação entre minério e lixo está a divisão/ relação utilitarista (regida pela obsessão da eficácia) entre sociedade e natureza fixada nos últimos três séculos de história contemporânea. Daí os pressupostos por trás do uso que se faz da segunda estarem ideologicamente concatenados com o objetivo básico do ato produtivo: geração de lucro e reinvestimento visando mais lucro. Assim, se de Santa Tecla se extrai algo socialmente valioso, útil e indispensável ao modo de vida ocidental (minério), para lá retorna o que o mesmo ocidente vê como indesejável, nocivo, algo que, após rejeitado, deve ficar longe dos olhos, olfato e convívio social: o lixo. De fato, ambas estão mais próximas do que se pensa quanto aos riscos à saúde, danos materiais e psíquicos causados pelo que delas resulta. Tanto extração de matéria prima como geração de lixo trazem implícita a lógica do aumento infinito da produção mercantil e o ethos consumista associado a ela. Traço marcante da sociabilidade construída dentro do sistema capitalista, ambos (lógica e ethos), ao promover crescimento econômico, são não só exaltados por empresas, governos e corporações, mas vistos paradoxalmente como vitais para a geração de recursos destinados a "proteger a natureza" e remediar impactos ambientais. Não à toa, portanto, uma solução para áreas degradadas por minas (como antigas pedreiras) tem sido sua conversão em aterro, juntando-se num mesmo local as duas pontas mais à jusante e montante do processo de produção, circulação, consumo e descarte/reuso.

\footnotetext{
2 Locais atingidos por grandes empreendimentos que, pela desvalorização e degradação da área combinada com a fragilidade política e social da população local, tornam-se atrativos a vinda de novas empresas e atividades também deletérias ao ambiente (ACSELRAD, 2010).
} 
No caso de Santa Tecla, esta tem sido alvo, vítima e, para a indústria do lixo, depósito de ações que causam angústia, perdas materiais e apreensão diante das perspectivas (ou falta delas) futuras. Como se verá, à população a contrapartida das minas e do lixo têm sido a baixa qualidade de vida e mesmo a produção deste rebaixamento, com as pessoas expostas, entre outros impactos, a: perdas de produção agrícola, contaminação de fontes dágua, doenças à ela ligada, depreciação de imóveis, explosões que atingem quintais e casas, além do estigma de morar ao lado de um lixão/aterro, com seus odores e chorumes lançados no ar, rios e terra.

Tendo este cenário por base, o artigo analisa as relações de poder ligadas aos danos causados pela mineração e lixão/aterro. Igualmente, mostra o quanto tais atividades, em princípio distantes, tem em comum no que toca à produção de injustiça ambiental e suas implicações. Estando em locais distintos, para fins de análise fez-se uma divisão entre "núcleo da mineração" e "núcleo do aterro/lixão". Neste último núcleo há uma nítida distinção social entre moradores do "entorno" e da Vila Tripa. No entorno e núcleo da mineração a condição econômica é mais elevada, com moradores tendo profissões como comerciante, bancário, professor, paisagista e produtor rural, não exercendo atividades ligadas ao lixo. Já moradores da Vila ${ }^{3}$, formada por habitações precárias, sem infraestrutura, uso clandestino de eletricidade e abastecimento da água via poço, vivem da coleta e reciclagem de lixo. Há ainda diferenciação entre quem trabalha com o lixo, divididos entre associados da Associação de Recicladores Santa Tecla (ARST), cooperados da Cooperativa Trabalhadores Carroceiros e Catadores de Material Reciclável (Cootracar) e catadores autônomos.

Os resultados baseiam-se em pesquisa de campo feita entre 2014 e 2016 a partir da observação implicada junto aos afetados pelas minas e lixão/aterro. Além do uso de jornais, fontes documentais e de um dos autores trabalhar há oito anos em Santa Tecla, foram realizadas 48 entrevistas com moradores (24 em cada núcleo) e sete com técnicos de órgãos de Gravataí e Porto Alegre. Na localidade há uma luta simbólica pela definição do depósito de lixo como "aterro" ou "lixão", o que se reflete no próprio nome das duas organizações que se contrapuseram a ele, ambas trazendo lixão no nome: Movimento Xô Lixão

\footnotetext{
3 Nos estados da região sul "Vila" é o nome dado a localidades normalmente qualificadas como "favela".
} 
e Associação de Moradores das Adjacências do Lixão Santa Tecla ${ }^{4}$ (Amalst); já integrantes de órgãos oficiais reforçam sempre se tratar de um "aterro". Assim, sendo categorias nativas que circulam em diferentes contextos, para marcar tal disputa adotou-se o termo "lixão/aterro". Por fim, como se trata de um contexto conflituoso, optou-se por não identificar as pessoas e usar termos genéricos como "morador", "entrevistada" ou ligado ao seu ofício ("catador", "professor").

\section{CONFIGURAÇÃO DE SANTA TECLA COMO "ZONA DE SACRIFÍCIO"}

Apesar de município de médio porte (255 mil habitantes) e com vasta área rural $\left(342 \mathrm{~km}^{2}\right)$ em relação à área urbana $\left(121 \mathrm{~km}^{2}\right.$ ) (IBGE, 2012), Gravataí, que inclui Santa Tecla, priorizou nos últimos cinquenta anos o incentivo a atividades ligadas aos setores da indústria, comércio e serviço. A área rural tem sido preterida pelo poder público, reforçando a invisibilização de uma população que, apesar de heterogênea, majoritariamente compartem o baixo poder aquisitivo e moradias em locais de alta vulnerabilidade social. No caso de Santa Tecla, esta se tornou polo de atração de empreendimentos que impactam o ambiente de forma direta e indireta, estando entre eles mineração, passagem de gasoduto, instalação de lixão/aterro, extração de terra, fábrica de postes de concreto, fraldas, ração animal e indústrias de menor porte.

A escolha de locais como Santa Tecla para tais atividades não é aleatória. Viegas (2015, p. 1), ao falar da injustiça ambiental por trás das "zonas de sacrifício", nota que a sobreposição de obras "responsáveis por danos e riscos ambientais" tende a ocorrer em "áreas de moradia de populações de baixa renda onde o valor da terra é relativamente mais baixo e o menor acesso dos moradores aos processos decisórios favorece escolhas de localização que concentram,

\footnotetext{
4 A Amalst, fundada em 2003 por moradores, teve como principal bandeira o fechamento do aterro/lixão e exerceu até 2005 papel importante ao denunciar a deposição irregular de lixo. Já o Xô Lixão, criado em 2005, teve forte atuação na resistência à vinda de outro aterro à Santa Tecla, chegando a levar 200 pessoas à uma audiência na câmara de vereadores de Gravataí. Porém, por falta de espaço, os confrontos com a administração do lixão/aterro, a luta contra novos depósitos de lixo e a história de enfrentamento da comunidade às ações da mineradora não serão aqui abordados. Para uma análise sobre o tema, ver Araújo (2017).
} 
nestas áreas, instalações perigosas". Já Acselrad (2010, p. 214) comenta que sua recorrência espacial atinge sobretudo "vítimas da contaminação de espaços não diretamente produtivos, como entorno de grandes empreendimentos portadores de risco e periferias das cidades onde são localizadas instalações ambientalmente indesejáveis (lixões, depósitos de lixo tóxico etc.)”. Neste caso, conforme Gerhardt (2014, p. 68), "trata-se do reconhecimento explícito de que, para se atingir um suposto bem maior, teriam que existir e ser criadas o que integrantes dos movimentos por justiça ambiental chamam de 'zonas de sacrifício'”.

Note-se que um dos motivos de Santa Tecla atrair tais "instalações" e ter o valor da terra "baixo" se deve justamente ao fato de se tornar uma zona de sacrifício. Aqui há um duplo movimento que se retroalimenta. Acselrad, Mello e Bezerra (2009, p. 21) lembram que "a atribuição desigual dos riscos ambientais está na relativa fraqueza política de grupos sociais residentes". Ora, se a baixa influência política aliada à exclusão econômica torna tais áreas propensas a receber obras impactantes, sua instalação atrai outras empresas também nocivas, gerando um ciclo vicioso que se nutre das fracas condições de organização local e, com o tempo, da criação de dependência por trabalho e renda em relação às empresas. Situação que se soma à sua vinda (efetiva ou meramente anunciada) criar expectativa de empregos e atrair um público sem vínculo (histórico, familiar, afetivo) com o lugar, gerando disputas internas e situações de conflito, além de dificultar a articulação local para fazer frente à sua instalação. Como resultado, tanto os que lá já viviam como quem chega têm de conviver com o que Stangers e Pignarre (apud MELLO, 2009, p. 28) chamam de “alternativas infernais', situações que não parecem deixar escolha a não ser a resignação ou uma denúncia que soa vazia, marcada de impotência, porque não oferece possibilidade de tomada de ação".

Santa Tecla insere-se neste contexto de produção de injustiça ambiental. Além do solo propício à extração de rocha e deposição de lixo, há facilidades logísticas, pois faz divisa com cidades da região metropolitana e vizinhança, que interessam tanto às mineradoras como à prefeitura de Gravataí. No primeiro caso, isto se dá pelo baixo valor agregado do minério fazer com que seja extraído próximo ao seu destino, tornando o custo menor e o negócio rentável. Tal 
condição espacial privilegiada leva à abertura de mais minas que irão abastecer atividades ligadas à construção civil regional. No segundo, a proximidade dos "produtores de matéria prima", isto é, do lixo metropolitano, e o fato de haver locais "adequados" (degradados) para depositá-lo (antigas minas desativadas e de extração de argila) mobiliza não só interesses econômicos, mas políticos, locais e de cidades vizinhas, que atuam no sentido de fazer com que o lixão/ aterro siga indefinidamente operando e amplie sua capacidade de receber lixo, além de pressionar para que sejam criados novos lixões/aterros na região.

A isto se soma a chegada de novas atividades, com a mineração atraindo a vinda de uma fábrica de postes que, além de poluente, tem íntima ligação com as minas de rocha pela composição da matéria prima usada (areia, brita e cimento). Algo parecido ocorre com o lixão/aterro, cuja presença, somada às áreas já degradadas pelas minas, fez com que uma multinacional tentasse instalar em 2006 outro aterro sanitário, dez vezes maior (em área e volume) do que o atual, e que receberia lixo até mesmo de Santa Catarina ${ }^{5}$. Fechando o ciclo, as duas atividades (minas/fábricas e lixões/aterros) geram outro duplo (e perverso) movimento. Por um lado, as minas depreciam imóveis e terras devido ao impacto que causam, afastando moradores, visitantes, turistas e possíveis compradores. Processo incitado pela própria prefeitura ao preterir investimentos no turismo e agricultura local em detrimento da extração mineral e deposição de lixo. Além disso, a vinda do lixão/aterro fez com que novos moradores (catadores e recicladores) se instalassem em busca de trabalho sem que lhes fosse garantido acesso a direitos básicos como saneamento, saúde, transporte e segurança, levando à formação da Vila Tripa numa área vizinha ao lixão/aterro.

\section{NÚCLEO DA MINERAÇÃO}

A conversão de Santa Tecla em zona de sacrifício remonta à construção da autopista que liga a capital ao litoral gaúcho nos anos 1970 e do parque

A Vega, holding do Grupo Solví, empresa que atua no segmento de coleta e deposição de resíduos, gerencia diversos aterros na América Latina. Para uma análise deste processo, ver Araújo (2017). 
industrial de Gravataí. O avanço das obras do período do "milagre econômico" (1969-1974) intensificou a mineração. Se no início causou forte êxodo rural e reforçou desigualdades, logo ocorre um movimento migratório contrário que levou à formação de bairros pauperizados, urbanização precária e favelização do município. Disto resultou a criação de uma população disponível (pela falta de trabalho e subemprego) que deu condições para expansão de ações ligadas ao setor industrial e extração de matéria-prima. Em Santa Tecla a exploração sistemática do solo inicia em 1973 com a Serra Almeida, primeira mineradora com maquinário apropriado para extração de brita e que passa a fornecê-la à construção da RS-118 e outras obras realizadas em Porto Alegre e região metropolitana. A partir daí a mineração se expande até 1986, quando a Serra Almeida é comprada pela empresa Guaporense que, em 1989, passa à família Zandoná, mudando o nome para Vera Cruz Pedra Mineração e Pavimentação. Esta tem hoje 220 ha no local, sendo 48 explorados pelas minas, com média de cem empregados e produção de mil toneladas de brita/dia.

No caso da mineração ilícita, recorrente na região, retira-se a pedra grés, cuja extração é feita sem explosões. Mesmo implicando menos impacto direto, o fato de ser ilegal a torna nociva noutro sentido, pois não há fiscalização. Além disso, em 2012 inicia a extração de argila. Esta, como a retirada de pedra grés, acarreta drástica alteração da paisagem natural e atinge intensamente a população na época de chuva por provocar deslizamento do barro nas estradas, impedindo a passagem e causando acidentes. Em 2015 denúncias feitas à Fundação Municipal de Meio Ambiente de Gravataí (FMMA) fizeram com que a exploração fosse interditada por alguns dias, voltando a operar em seguida. Embora a extração de argila tenha cessado novamente em 2017, nada foi feito para sanar as imensas crateras abertas à beira da estrada Henrique Closs, principal via de acesso ao centro de Gravataí e cidades do entorno.

\section{A rotina e o corriqueiro: excesso de velocidade, fluxo e peso/ carga dos caminhões}

A queixa mais recorrente em relação à mineração não resulta da extração em si, mas da precariedade da Henrique Closs devido ao tráfego de caminhões, 
os quais andam descobertos, sem lona, com excesso de peso e alta velocidade. Foram vários os relatos de atropelamentos e situações de risco que, como dizem as pessoas, não causaram acidente "por sorte". Segundo uma moradora, "meu filho de 14 anos quase foi atropelado outro dia ao descer do ônibus; a estrada é perigosa pras crianças que atravessam pra ir à escola que fica do outro lado, porque não tem acostamento". Na estrada cruzes sinalizam e confirmam as mortes. São em torno de $8 \mathrm{~km}$ entre a RS-118 e a sede da mineradora. As mortes provocadas pelo tráfego e o estado de conservação (que faz com que veículos transitem na contramão) atinge tanto motoristas quanto pedestres vítimas de atropelamento, situação agravada, segundo outra entrevistada:

"porque os caminhões tão sempre em alta velocidade, é cheia de buracos e não tem acostamento. [...] outro dia a minha sobrinha de dois anos saiu do pátio e estava indo em direção à estrada; e bem na hora vinha uma carreta em alta velocidade e só deu tempo de outra menina segurar ela pela mão; e a carreta quase pegou ela. Tem muitas crianças andando nessa estrada sem acostamento."

A queixa se dirige a veículos à serviço da mineradora e empresas por ela contratadas. Além de tolhidos no ir e vir ao trabalho, estudo e demais afazeres, moradores convivem com o stress do risco constante. Dos 24 entrevistados no núcleo da mineração, 18 se sentem muito afetados pelo estado da estrada, o qual atinge a todos independente do meio de transporte, afetando pedestres, motoristas e condutores de carroças que levam lixo. Quem usa transporte público também é lesado com o serviço irregular e quebra de ônibus somadas às poucas linhas e horários oferecidos. Para uma moradora "a estrada é péssima e me sinto prejudicada porque dependo de ônibus; e eles atrasam e não cumprem horário por causa da estrada ruim".

No trecho que passa pelo núcleo do aterro/lixão, os problemas são ainda maiores, pois absorve o trânsito das duas atividades. Segundo um morador, "no auge do aterro eram caminhões a noite toda, funcionava 24 horas"; outra moradora diz que "na época do lixão era um caminhão passando em menos de 20 minutos; estremecia tudo em casa". Também o número de pedestres é 
bem maior neste núcleo, sobretudo crianças da Escola Humberto de Campos, o que faz com que atropelamentos sejam frequentes. Na Vila, à beira da rodovia, como a maioria usa transporte público, o tráfego intenso marca a memória dos moradores, com pesares que não podem ser facilmente avaliados. Um morador conta que caminhões "andam em alta velocidade e na contramão. Perdi um irmão com 24 anos que se acidentou de moto na Henrique Closs, bateu em um caminhão numa curva. O filho de um amigo, de 14 anos, aluno da escola Santa Tecla, faz quatro anos também foi atropelado na estrada e morreu". Para este morador "os caminhões passam com tanto excesso de peso que treme dentro de casa, não tem fiscalização". E uma moradora lembra: "muita coisa mudou, sinto falta da calma e tranquilidade, isso já não existe mais, na semana são os caminhões pesados em alta velocidade e no fim de semana motoqueiros que fazem trilha de moto". Em suma, conviver com caminhões, barulho e tremores faz parte da rotina de Santa Tecla.

\section{Entre explosões, rachaduras, pedras, sirenes e deslocamento forçado}

O segundo impacto citado por quem mora perto da mina foram as explosões de rochas. Quanto mais perto das detonações, mais forte são sentidas, com rachaduras na parede e vidros quebrados que exigem constante reparação. Um morador que viveu ao lado da mina comenta: "a exploração acontecia de qualquer jeito, sem planejamento nenhum. O barulho era ensurdecedor, vinha sem aviso prévio e algumas vezes por dia". Mas para quem continua no local o tormento é parecido, caso da família de outro morador: "passo trabalho com os sustos; e medo. Do que mais tenho são rachaduras nas paredes, vidros quebrados; e ainda por cima não posso mais criar animais como antigamente". Fissuras nas paredes são visíveis em quase todas as casas perto da mina e algumas no núcleo do lixão/aterro. Conforme uma moradora deste, "tô distante quase três quilômetros da mina e minha casa é cheia de rachadura; a cada explosão tudo estremece e as paredes trincam". Já quem vive próximo às detonações sofre não só com poeira, rachadura e ruído, mas com o risco de ser atingido pelas pedras lançadas nas explosões: "os prejuízos para nós eram piores, a 
casa era cheia de rachaduras e o medo de cair as pedras na nossa cabeça era um verdadeiro terror". De fato, a vida destas pessoas é difícil, submetidas à tensão diária. Uma ex-professora da Escola Santa Tecla conta que

"eu e meus filhos saíamos correndo para longe, mais ou menos um quilometro, para nos escondermos durante as explosões. Muitas vezes não nos avisavam e quando tocava a sirene tínhamos que correr para baixo da mesa da cozinha, pois as pedras caiam em cima da minha casa, galpão, pátio; e às vezes detonavam a noite também."

Além de não avisar quando ocorreria detonação, só depois “ia um funcionário na minha casa para saber se estávamos todos bem, mas nunca antes pra avisar". Apreensão que se vê na fala de outra moradora: "as explosões me assustam, quase engoli a bomba do chimarrão um dia, distraída da sirene". Uma vizinha cujo terreno faz divisa com a mina diz "ter problema de audição e muitas vezes estou sem o aparelho e não consigo escutar a sirene que sinaliza as explosões. Tenho verdadeiro pavor com o estrondo. Minha casa estremece, passo muito mal".

Entre "sustos" e "medos", viver tal situação - que lembra cenas de guerra, com sirenes tocando, pessoas correndo em busca de abrigo, bombas explodindo e estilhaços caindo sobre as casas - levou parte dos moradores a vender ou permutar a terra com a mineradora. Caso da ex-professora citada cujo descaso intencional com as explosões foi usado pela empresa para "pressionar a venda de 27 hectares". Após 10 anos resistindo, mudou-se para fora da área de detonação. Mas a aflição continua para quem fica: "pedras voam sobre a minha casa e caem no galpão e na área. Já caiu até na cozinha”. E uma vizinha se queixa:

"é difícil criar animais por causa da mineradora. Meus cachorros têm muito medo e uivam o tempo todo por causa das explosões. Os tremores são horríveis. Minha casa está toda rachada e quase não tem vidro inteiro nas janelas. Se elas estiverem abertas, os vidros quebram todinhos."

Já quem mora perto da britagem ${ }^{6}$, além do ruído, há o risco da conservação de explosivos, como conta um vizinho da empresa: "só fui me dar conta

\footnotetext{
Beneficiamento da rocha a partir da sua fragmentação feita com equipamentos que causam forte ruído.
} 
do risco e o quanto tô vulnerável quando a empresa foi invadida e assaltada por causa dos explosivos. Não sabia que armazenavam tanto".

Uns mais, outros menos, os relatos mostram como a mineração afeta a vida das pessoas. Se explosões funcionam como mecanismo de pressão, a proximidade da mina afasta a vinda de novos sitiantes. Com isso a empresa se beneficia duplamente: pela ação negativa sobre o imóvel, que espanta possíveis compradores; ao gerar com as explosões uma contínua aflição em quem lá mora, levando a busca por outro local para viver (alternativa infernal diante da opção de ficar). E se não logra vencer espontaneamente a resistência de quem fica, a empresa oferece valor abaixo do mercado por suas terras: "a maioria dos meus vizinhos foi embora, vendeu sua propriedade para a mineradora por pouco dinheiro ou trocando. Me ofereceram uma troca, mas não aceitaram o sítio que escolhi”. Já ao tentar vender a terra através de imobiliárias, como muitos não tem a terra titulada, obtêm um valor também inferior. Disto resulta que uns são mais lesados que outros em relação à depreciação da terra, sendo o critério a distância da mina. Note-se aqui a inversão de prioridade: ao invés de explosões serem vistas como incompatíveis com a qualidade de vida das pessoas, sua presença é que se torna inconciliável com a permanência da mina: da equação "explosão incompatível com moradia = fim da mineração", tem-se "moradia incompatível com mineração = expulsão de moradores".

\section{POEIRA, ARROIOS SECANDO, PERDA DE ATIVIDADES RURAIS E DESTRUIÇÃO DA PAISAGEM}

Por vezes a espessa névoa que se acumula no morro Santa Tecla torna a poluição do ar visível, mas no geral ela passa despercebida para quem não mora no local, com o pó de explosões e caminhões carregando pedras atingindo fortemente a população. Conforme uma moradora, "poeira não adianta limpar, limpo pela manhã e à tarde já está coberto novamente, tenho rinite e minha filha nem me visita muito por causa da poeira, porque quando vem passa muito mal". Além do esforço e gasto para manter a casa limpa, o pó afeta 
a saúde, sendo a rinite o problema mais citado. Cerca de $88 \%$ dos entrevistados (21 pessoas) no núcleo da mineração tem algum tipo de doença respiratória. Dado que, caso não possa, ser tomado como prova de que todos os casos decorrem da exposição à poeira, é forte indício de que parte expressiva dos moradores tenha sido afetado por ela. Mas o caso pode ser mais grave, para uma moradora, cuja mãe tem bronquite e sempre viveu no local, "não foram poucos os trabalhadores, não dessa empresa, da anterior, que morrerem por causa da exposição à atividade". E um vizinho disse terem sido "vários os casos de pessoas que trabalharam a vida toda na mineração e tiveram problemas de saúde e depois faleceram por conta disso".

Também a criação de animais é afetada, segundo um morador, "minha propriedade tem nove arroios e os animais vivem soltos. Próximo às detonações tenho de sair correndo catando os animais pra se abrigarem das pedras. Às vezes não consigo pegar todos e as pedras passam raspando pelos animais, que ficam muito assustados". As detonações "atingiram diretamente as vertentes e $80 \%$ já secaram. E toda vizinhança da mineradora que usava as terras para desfrute [de animais] e outras finalidades teve de sair e vender sua terra" para a empresa. Tanto explosões como outras etapas da extração (britagem, decapagem) pioram a qualidade da água dos arroios, assoreando cursos d'água e, com isso, provocando alagamentos. Segundo uma antiga vizinha da empresa "o arroio está assoreado por causa da mineradora, aterraram lá em cima no morro e a terra desce com a chuva, caindo no mato e depois no arroio Santa Tecla. Nem minhas terras são mais as mesmas por causa disso, imagina o arroio"7. Já um integrante dos Patrulheiros Ecológicos São Francisco de Assis conta que o arroio (Martins)

"está aterrado com o depósito de areia e brita e poluído pelo óleo, enxofre e outros produtos químicos, o que levou a perda de mata ciliar. A paisagem foi destruída onde está a mineradora. Lá não existe mais morro, chegando a soterrar e transferir o leito do Rio das Sangas, da Sanga dos Padres, Sanga dos Morretes [...], que se unem e deságuam nos arroios Santa Tecla e Martins."

\footnotetext{
Desde 2014 as escolas alertam a empresa do assoreamento dos córregos e solicitam reposição de mata ciliar e cercamento da área que dá acesso à estrada e ao arroio. Porém, a mineradora disse que não faria as obras de recuperação e ofereceram 500 reais para a escola resolver ela própria o problema, que ficou sem solução.
} 
Este já foi a principal fonte d’água para criação e irrigação da plantação. De algo querido por moradores o arroio Martins tornou-se um problema: por estar assoreado, quando chove alaga e seca em épocas de falta de chuva. Sobre o valor dos arroios para a população, lembra um morador: "hoje já não tem mais peixes nos arroios, nem ratões do banhado. Os arroios eram usados pela comunidade e serviam pros animais e pra consumo da casa, até pra cozinhar. Hoje isso é impossível. O arroio perdeu a utilidade pra comunidade". Segundo ele, a mineração destruiu "a paisagem e a memória histórica com a aniquilação da Sanga dos Padres e de um antigo cemitério jesuíta". Além da supressão de espaços de sociabilidade/lazer, como banhos e pescarias, a maior parte do morro Santa Tecla onde se faziam passeios sumiu. Para quem tem mais de 40 anos, restam lembranças que remetem à infância e convívio com parentes, vizinhos e pessoas próximas. Um morador, ao lamentar a perda de três "cachoeiras e uma paisagem exuberante, com uma variedade de animais", recorda de um lugar hoje inexistente: "é onde me criei, onde meus amigos estão, conheço todo mundo, minhas raízes. Sinto pela transformação, pela perda da natureza, sinto falta de como era antes".

\section{Um negócio de família e uma "cordial" chantagem}

Há sazonalidade na abertura das minas, com as queixas mudando conforme migra o veio de pedra explorado. No caminho estão mais custos às famílias por ter de reforçar suas casas. Uma moradora teve de cobrir a varanda para não ser alvejado por pedras: "no meu aniversário minhas amigas vieram passar à tarde comigo e tivemos de correr pra debaixo da chapa por causa das detonações, elas ficaram apavoradas". Citada por várias pessoas como quem mais sofre com o avanço das minas, o presidente da Amalst conta que foi "um dia levar uns produtos pra ela. Fiquei tão chocado com o problema que ofereci ajuda com advogado para processar a mineradora, mas ela depois de pensar a respeito se esquivou da oferta".

Tal recusa tem sua razão. Apesar da alta incidência de problemas, há poucas denúncias de danos pelas detonações porque muitos moradores não podem pedir indenizações por não ter o "habite-se", certidão comprovando que o imóvel segue exigências legais da prefeitura, sendo necessária ao pleito 
judicial e ressarcimento de prejuízos. Soma-se a já citada ausência de título fundiário de parte dos proprietários, também exigida nestes casos. A mineração foi pouco a pouco naturalizada e abstraída pela comunidade. Apesar das queixas constantes das explosões, poeira, deslocamento forçado, perda de atividades rurais, depreciação da terra, destruição da paisagem, excesso de peso e fluxo de caminhões, poluição e assoreamento de cursos d'água, problemas respiratórios, danos às moradias e a pressão psicológica exercida pela empresa, reações são esporádicas e individualizadas.

Uma primeira explicação recai na postura assistencialista da empresa ao fazer pequenas "doações" a igrejas, escolas, CTG, festas e outros eventos, além de empregar moradores na mineradora. Apesar de 15 entrevistados dizerem não ter vínculo, quatro trabalham, três já trabalharam ou tem parentes que trabalham e dois se aposentaram por ela. Além da influência direta sobre quem é empregado, ela se estende à família, sendo uma das queixas da população a política de empregar só uma pessoa do núcleo familiar, prática que restringe o acesso aos empregos e ao mesmo tempo mantém refém um contingente expressivo de pessoas, visto que se contrapor à empresa pode levar à perda do emprego de um parente ${ }^{8}$. Além do emprego de familiares que podem oferecer alguma resistência, é usual distribuir cargos a pessoas com algum prestígio ou influência local (lideranças políticas, carismáticas ou que tenham inserção junto à população) e que passam a gravitar na órbita da empresa em uma relação de dependência por vezes paradoxal, pois se dela dependem, são afetados e se sentem por ela intimidados. Se tal artifício tem alcance limitado pela própria escassez de trabalho ofertado pela mineradora, que prefere empregar gente de outros locais (o que é cobrado pelos moradores), sobretudo para quem mais sofre ou tem prejuízo com a atividade, cargos e mesmo a promessa de trabalho são usados como barganha. Ao final, é difícil para a família do funcionário e a ele, por temer represálias e estar enredado por laços de parentesco, ter uma postura mais crítica e firme ou ingressar com possíveis ações judiciais contra a mineradora, ainda que ela o atinja diretamente (e diariamente).

\footnotetext{
8 Como o emprego na mina é algo fundamental para quem nela trabalha, neste caso específico não se fez citações de falas diretas das pessoas para evitar possíveis retaliações.
} 
A mineradora gera dependência não apenas pela oferta seletiva de postos de trabalho e de práticas assistencialistas. Ao estimular indiretamente o comércio local e servir como fonte de renda pela simples presença na região, parte da comunidade é capturada pela expectativa de algum ganho monetário, como a vinda de atividades comerciais como restaurantes e prestação de pequenos serviços. Porém, a expectativa de obter algum "benefício" vêm junto com a alternativa infernal: pagar o custo ambiental inerente às minas ou sofrer com o não emprego e a não renda vinda da mesma. De todo modo, os artifícios descritos têm como efeito criar a percepção de que a presença da empresa é quase que necessária. Se Santa Tecla absorve seu impacto sem a devida contrapartida aos riscos a que está exposta, a resistência ocorre de modo isolado e pontual, com as pessoas se colocando contrárias ou em oposição à mineradora só quando diretamente atingidas, o que gerou ao longo dos anos muitas reclamações, poucas denúncias, raros processos e fraca mobilização.

\section{NÚCLEO DO ATERRO/LIXÃO}

A deposição de lixo em Santa Tecla iniciou com um lixão a céu aberto na década de 1970 e que funcionou até 1998, quando ganhou status de "aterro sanitário". Lá criava-se porcos e extraía-se argila até que a família dona da área passou a receber de restaurantes de uma cidade vizinha restos de comida para alimentar a criação. No início o lixo ficava longe da casa e os porcos eram criados livres nesse espaço, mas os caminhões aumentaram na década de 1980, os donos passaram a serem pagos em dinheiro e o lixo colocado nos buracos deixados pela extração de argila, com o local recebendo resíduos de toda espécie (sólido, hospitalar, químico). Mau cheiro e incêndios tornaram-se comuns, com uma fumaça escura que afetava sobretudo crianças. A partir da mobilização em torno da Associação de Preservação da Natureza do Vale do Gravataí (APN-VG), em 1997 o lixão é interditado pela prefeitura e, após reestruturado em 1998, voltou a operar como aterro sanitário. Ampliado em 2004, a desapropriação da área e terras contíguas fez com que as famílias expulsas ocupassem a área ao lado do 
novo aterro, dando origem à Vila Tripa. Gerido por um consórcio entre Porto Alegre, Esteio, Gravataí e Cachoeirinha, este foi exibido como obra "saneadora" que, através de tecnologia, resolveria o impacto da deposição de lixo ao mesmo tempo em que não geraria risco à população local.

No início, Vila Tripa viu a intervenção com bons olhos, pensando que daria fim ao incômodo com o lixo. Mas a "melhoria" trouxe novos problemas, pois o volume depositado cresceu drasticamente enquanto leis ambientais eram constantemente infringidas. Apesar do discurso oficial sobre sua "sustentabilidade" e eficiência, o dilema infernal surgiu para os moradores ao ter de optar entre conviver com mau cheiro, incêndio, ratos, água contaminada e problemas de um lixão à céu aberto e aceitar uma obra de dimensões gigantescas (em área e volume de lixo) que não resolveu as questões do cheiro, água e ratos. O que parecia uma solução técnica conduzida por peritos (sendo criada uma agência estatal para tanto) tornar-se-ia não apenas promessa não cumprida, mas motivo de mais transtorno e dor de cabeça.

Não sendo foco do artigo, não se abordará aqui a história da luta local contra a deposição de lixo (cf. ARAÚJO, 2017). Basta dizer que, pelo projeto, o "aterro", que deveria durar cinco anos, mesmo com sua capacidade esgotada, teve sua existência sistematicamente postergada por 16 anos, operando a maior parte do tempo ilegalmente ou por liminares. O clímax do descontrole ocorreu em 2014 com o maior vazamento de chorume na história do local, com impactos de grandes proporções. Hoje, além da alteração da paisagem e do efeito visual negativo, tendo como adendo o convívio com garças e urubus que comem no aterro e defecam nas terras e no pátio de seus vizinhos, do lixo depositado resulta um passivo ambiental de mais de um milhão de toneladas.

\section{Desapropriações, reocupações, perda de atividades produtivas e qualidade de vida}

Embora quem viva no núcleo da mineração também carregue o signo social de morar perto de algo "sujo", além de maior risco à saúde e o mau cheiro, moradores da Vila Tripa e entorno do aterro/lixão são quem mais sofrem com os impactos devido à proximidade. Por sua dimensão (81 metros de altura), a 
poluição do ar, da água e do solo é sentida de forma constante. Segundo duas famílias, ex-proprietárias da área onde está o lixão/aterro, além da desvalorização da terra e benfeitorias, não receberam todo valor devido da transação. Diz uma dessas pessoas, que hoje faz frete com sua carroça, "a gente era agricultor, tinha vaca leiteira, cavalo, porco, plantava e tinha pomar. A propriedade tinha 10 ha e por causa do lixão deram o preço lá embaixo e disseram que era improdutiva, o que foi uma injustiça”. História parecida a outro ex-proprietário: "a terra estava com a família desde meu bisavô há mais de 200 anos e era documentada. A família sabia o quanto era importante conservar a terra comprada com muito sacrifício pelo meu bisavô, que deixou pro meu avô e depois pro meu pai".

Conforme o filho de outro antigo dono da área onde hoje está o lixão/ aterro, além da coação até o despejo, tiveram de "viver de favor" na casa de parentes até retornar como "invasores" do que antes era sua terra: "sofremos violência física e humilhação. A gente não iria sair daqui nunca, minha família se esforçou pra comprar as terras, fomos criados aqui e educados a nunca vender". Segundo ele, sua família ficou até o último instante do despejo. Relato parecido ao de outra moradora expulsa:

"deram um prazo, mas a gente não saiu e teve de sair correndo porque
as máquinas derrubaram as casas e não deu tempo de tirar as coisas
de dentro. Peguei meus filhos e um neto de 10 meses e fomos larga-
dos na estrada. A indenização foi uma mixaria e não pagaram antes da
gente sair. Aí fomos pra casa de amigos e depois de um mês voltamos."

Dessa ocupação resultou a Vila Tripa, onde juntaram outras famílias, muitas vezes amigos e parentes de quem lá estava, como conta outro morador: "meu pai trouxe alguns amigos e pessoas que precisavam. Depois outro casal também foi trazendo seus parentes". Hoje a Vila tem 24 casas e parte das famílias têm laços de parentesco direto e indireto. A nova realidade, criada pelo Estado quando da "modernização" do lixão, levou a outros problemas: "perdi cavalos que fugiam e iam pro aterro e os guardas prendiam e, como era proibido, perdia o bichinho". Além da fuga de animais, as famílias foram impedidas 
de cultivar suas roças e criar seus animais, caso de um morador do entorno, que alegou não ter "mais como plantar, ter pomar, porque as frutas adoecem e caem antes de se desenvolver".

Diferente do núcleo da mineração, sendo uma ocupação "irregular", com as pessoas sob constante ameaça de expulsão, na Vila, a depreciação do imóvel não é uma questão. Exceto na memória de quem lá viveu, pouco resta do cenário de outrora. Para um integrante da ARST:

"antigamente era muito melhor. Me criei aqui, a paisagem era bonita. Antes do lixão o lugar era outra coisa, a gente tinha animais e plantava aipim, cana, tinha vaca e tirava leite". Outra moradora lembra que a família tinha "alambique, tafona de farinha e os pais plantavam e criavam animais."

O neto de antigos proprietários lastima: "foi a pior coisa que meu avô fez. Por causa de dinheiro aceitou pôr lixo na terra dele e deu no que deu. Hoje não temos mais terra, tivemos de invadir, porque nunca pagaram direito e mandaram sair sem ter recebido o dinheiro". E se os mais jovens se ressentem do que pouco viveram, como ter ao lado árvores frutíferas e um roçado, para a mãe de um deles viver do lixo foi a alternativa que restou: "meus filhos foram criados na montanha de lixo e lá brincavam até de escorregador".

Além da frustração de quem levava a vida próxima à natureza, sem poluição, cheiro nauseante e longe dos transtornos diários da cidade, o lixão acabou não apenas com o direito de usufruir como gostariam o espaço onde vivem, mas de não partilhá-lo com amigos e parentes, situação descrita por um entrevistado: "uma vez me senti humilhado, porque tava dando um churrasco e tinha bastante convidados e começou o cheiro ruim, insuportável. Fiquei com muita vergonha, acabou com o churrasco, porque ninguém conseguia comer".

\section{Anestesiando sentidos: 0 cheiro e o estigma}

Com a reconversão cresceu o volume de lixo e o cheiro ruim. Nas entrevistas pedia-se às pessoas indicar, entre algumas alternativas, as que melhor definissem o incômodo com o lixão/aterro, sendo o mau cheiro o principal problema citado. De oito entrevistados no entorno, só um diz não se importar 
com o cheiro. Uma moradora que mora na frente da Vila disse se sentir muito afetada pelo fedor, tendo problemas de rinite, alergia no rosto, dores de cabeça e estômago, melhorando com o fim da deposição de lixo. Para a proprietária de um sítio no entorno "o que mais me incomoda é o cheiro, é insuportável". Em 2008, outra moradora dizia ao Correio de Gravataí (TORRES, 2008, p. 9): “até mês passado tava pior porque não estavam movimentando muito. Aí ficava aquele lixo todo ali jogado. Mas o dia que faz muito calor é um horror. Na verdade, é algo mais perceptível do que visual". De fato, o odor, para quem passa pela localidade, parece vir de lugar algum. Mas se em uns provoca forte incômodo, para outros não é tão relevante. Diferente do entorno e núcleo da mineração, na Vila, o convívio com o cheiro varia de um mal menor a um não problema. Para uma recicladora "o cheiro do aterro nunca foi problema, me acostumei". Também para uma moradora expulsa após a ampliação do aterro, "o cheiro não incomodava, já tava acostumada, os parentes quando iam na minha casa reclamavam [...], mas nós não, a gente só sentia quando saía e depois voltava, aí sentia que era realmente bem forte, mas depois passava".

Por precisarem do lixo para viver, quem mora na Vila tem com este uma relação distinta do resto de Santa Tecla. A experiência de ter de se adaptar a situações de insalubridade e, por vezes, trabalhar desde criança com o lixo fez com que o cheiro virasse algo normal (o que, como se verá, ocorre com a poluição de poços artesianos), tornando-se suportável e até mesmo não perceptível; como alegou uma recicladora para quem o odor não é mais notado: "tu acostuma e não sente mais". Soma-se a dependência econômica de quem trabalha com o lixo, que faz com que seus efeitos sejam minimizados, caso de uma das criadoras da ARST, para quem o lixão garantiu renda por 20 anos: "com o lixão não me queixava de dinheiro, a falta dele é pior que o cheiro, esse não é nada, nem sentia". Preferir sentir "o cheiro" à "falta de dinheiro" (que "é pior", pois embora se conviva com o primeiro, não significa que seja bom) revela a distinção de classe materializada geograficamente. Enquanto o cheiro não é um problema maior na Vila, a 2 km se faz sentir para várias pessoas do núcleo da mineração. Para uma integrante do movimento Xô Lixão, "quando era o lixão o cheiro e a fumaça incomodava e poluía, vinham até aqui. Com o aterro o lixo não deveria ficar a céu aberto, 
mas o cheiro e a poluição ficaram piores com o volume de chorume maior". E se o fedor é lugar comum no bairro, mesmo quadros da prefeitura admitem sua existência, como o responsável pelo controle do aterro/lixão:

"o cheiro sempre teve e foi objeto de muita recriminação. Então nós tomamos como medida fazer uma cortina vegetal pra que parasse um pouco em dias de vento. $\mathrm{O}$ cheiro era inevitável e não porque estava sendo mal operado, mas porque sempre fica uma parte do lixo descoberto. Sempre tem que ficar uma frente descoberta enquanto tu está trabalhando."

Em síntese, diz o técnico: sendo o fedor inevitável, melhor resignar-se, fatalidade ocultada quando o aterro foi exibido como solução inovadora. Já para o ex-diretor da FMMA o odor viria da sua má operação: "toda obra tem tempo de vida e a coisa foi empurrada com a barriga até surgir problemas [...] em relação ao mau cheiro. Problema de má execução de técnicas corretas pra funcionar como realmente um aterro sanitário, até ser fechado". Mas o ex-diretor do Departamento Municipal de Limpeza Urbana da prefeitura de Porto Alegre (DMLU) tem outra explicação: "embora as pessoas reclamassem, não tinha cheiro. A cada 15 dias [eu] subia no aterro e o cheiro que sentia era da criação de porcos próximo ao aterro". Aqui inverte-se a visão de que conviver com o lixo 24 horas por dia o faz não ser sentido, pois subir o aterro a cada 15 dias teria aguçado o olfato do ex-diretor a ponto de discernir em meio a toneladas de lixo o odor de pocilgas vindo de locais distantes. Visão que culpabiliza as próprias vítimas que sofrem com a poluição, visto que, por sua conta e risco, teimam em criar porcos. Mas o olhar acusatório sobre quem vive do lixo também vem de quem mora em Santa Tecla. Conforme um integrante da Amalst:

"o pessoal da Vila Tripa convivia com o lixo de forma natural sem a mínima preocupação com higiene ou saúde. E um dia eu vi, ninguém me contou, um caminhão de lixo de supermercado com produtos avariados e vencidos chegar com ovos e cervejas tão quentes de ficarem o dia todo no sol que chegaram a cozinhar os ovos. E um dos proprie- 
tários da área do então lixão e criador de porcos simplesmente comeu os ovos e tomou às cervejas. Eu fiquei chocado. Acredito que muitas mortes de catadores podem estar associada ao lixo."

Embora este morador tenha feito duras críticas ao ex-diretor do DMLU, suas falas se aproximam. Além do juízo na "preocupação com higiene ou saúde" supor uma visão relativa à escolha pessoal e individualizante que retira de cena o contexto social vivido e eventos que levaram à formação da Vila Tripa, a culpa por "muitas mortes de catadores" recai sobre eles próprios, visto não cuidarem da sua alimentação e do que fazem com o que retiram do lixo. Já a visão dos catadores sobre sua relação com este é bem distinta, notando-se certa nostalgia do tempo em que o lixão funcionava, quando podiam "catar pra si"g sem restrição. Contrapondo o integrante da Amalst, para uma moradora que trabalha na coleta seletiva: "tudo que consegui foi com o lixo. No tempo do lixão a gente fazia muito dinheiro, comprei terreno e casa com dinheiro da catação, o cheiro era ruim, mas tinha trabalho, isso é o que importa”.

A principal marca do aterro/lixão está em se viver ao lado de onde se despeja "o que não presta mais", sendo que o estigma de viver perto do lixo começa já no nome do local onde vive a maioria dos catadores, a Vila Tripa. Na origem, o termo vem do seu formato, uma linha que contorna o lixão. Ocorre que "tripa" adquire conotação negativa se associada ao intestino, que liga o estômago ao ânus e onde se produz o "bolo fecal", outro tipo de dejeto. No núcleo do aterro/lixão quatro pessoas admitiram ter passado por situações incômodas. A avó de uma ex-aluna da escola relata: "minha neta sofria preconceito na escola, era chamada de lixeira pelas colegas". Outra moradora diz que quem mora na Vila é discriminado pelos próprios garis de Gravataí: "porque muitas vezes não recolhem nosso lixo. Acham que, porque vivo e moro no meio do lixo, não precisam recolher". Para quem não citou o preconceito, não significa que não exista ou seja notado, pois negá-lo pode ser um mecanismo de defesa e/ou uma forma de contrapor o próprio estigma do qual se é vítima. Já a relação dos moradores da Vila com o

\footnotetext{
9 O termo "catar pra si" é usado para se referir ao trabalho com o lixo sem mediação de intermediários
} (como a associação e cooperativa). 
restante da comunidade surge de modo ambíguo, havendo uma separação que se mostra só em certas situações e cuja amplitude depende do público envolvido. No núcleo da mineração, o estigma da Vila é em geral velado, porém, presente, como mostra a fala de uma moradora:

"preconceito acho que sempre houve, inclusive das pessoas aqui do bairro para com os outros bairros. Me parece que o pessoal daqui não se mistura, por exemplo, com o pessoal da Costa do Ipiranga porque são considerados brigões, violentos, as pessoas do Morro do Paula pela marginalidade e os do lixão por causa da sujeira do lixo. O pessoal daqui se considera elite do bairro e tem preconceito com a Vila."

Aqui há uma dupla distinção: externa, entre os que "não são daqui" e o "pessoal daqui"; e interna, entre quem se "considera elite do bairro" e "não se mistura" e "os do lixão", o "pessoal da Vila". Quando alguém se refere ao "pessoal daqui”, geralmente associa a pessoa ou família ser nativa do lugar. Já o "pessoal do lixão", mesmo tendo entre eles pessoas nascidas em Santa Tecla, é visto como morador recente. Mas seja "de fora" ou "de dentro", permanece o "preconceito com a Vila" ou que lida com o lixo, o que é notado pelos moradores, sobretudo os mais novos. Exemplo disso foi que, ao se visitar à Vila, era nítida a vergonha que os alunos da escola Santa Tecla sentiam do local onde moram, pois, sendo uma das autoras professora nesta, a cada casa que se ia as crianças se escondiam e poucos apareciam.

Sendo a distinção também externa, o efeito estigmatizante atinge os dois núcleos, como se vê na fala desta moradora do núcleo da mineração: "quando digo onde moro sempre dizem assim: - 'ah! Lá no lixão'”. Se criadores de suínos têm sua carne desvalorizada pela desconfiança de ser produzida a partir do lixo, a mesma "elite do bairro", diante de alguém de fora de Santa Tecla, sente o incômodo de ser visto como quem vive ao lado de um lixão. Referida a um atributo ao mesmo tempo concreto e subjetivo, esta marca liga-se diretamente à ideia de proximidade: quanto mais perto se mora do lixão/aterro, maior a força negativa; quanto mais longe, menor será. Como próximo e distante são categorias relativas, a intensidade da estigmatização dependerá de cada situação 
e do que é notado como longe e perto (Vila, entorno, estrada Henrique Closs, escola Humberto Campos, Santa Tecla etc.).

\section{Estratégias de vivência e reinvenção identitária: catação no- turna, guardas e porcos}

No tempo do lixão havia livre acesso aos resíduos, o que muda com o aterro. Como este implica controle e normas incompatíveis com a catação em contato direto com o lixo, a reconversão dificultaria muito seu trabalho. Mas a catação seguiu proibida, levando a um confronto constante com a gerência. Por sinal, esta por vezes via como positiva a atuação dos catadores, pois agilizava o trabalho, tamanho o volume de lixo depositado, como conta o então presidente da ARST:

a cada vinte caminhões que chegam ao depósito, quando as 50, 60 pessoas sobem para revirar o lixo, podem colocar mais dez caminhões em cima que terá espaço. Quando não tem ninguém lá para fazer esse trabalho, colocam os vinte e pronto. Mas na realidade todo mundo é consciente das leis. A ordem de não subir é dada, mas a necessidade ainda faz muita gente ignorar (AS MÃOS, 2009, p. 8).

Pelos relatos, chegou a 4 mil os porcos soltos à noite que se alimentavam enquanto seus criadores remexiam o mesmo lixo. Se ora a proibição era flexibilizada ora cobrada, havia o jeitinho. Para acessar "à flor" ${ }^{10}$, como dizem os catadores, passaram a "doar" porcos aos guardas para obter sua conivência. $\mathrm{O}$ silêncio pago com porcos é descrito por uma catadora: "era proibido, mas a gente catava igual e os porcos se alimentavam dali. Pagava os guardas com os bichos e, quando iam levar, tirava eles uma semana antes e deixava preso. Ia uns 15 porcos pra cada guarda". Separá-los antes da "doação" visava dar ração e não lixo, condição imposta pelos guardas que ilustra a rejeição à carne de porco de Santa Tecla. De fato, é fácil entender como tal construção do gosto se processou, fazendo com que a carne local fosse vendida em açougues e minimercados da região de forma clandestina e preço inferior.

${ }_{10}$ Para os catadores, trabalhar "na flor" indica a área do lixão/aterro onde está concentrado o "melhor lixo". 
O maior controle sobre a catação se deu com Porto Alegre na gerência, em 1998, no breve período em que a Fepam concedeu licença de operação ao aterro/lixão, pois ela não foi renovada, operando desde aí a maior parte do tempo por meio de liminares, mandatos de segurança ou de modo irregular ${ }^{11}$. Segundo um morador, após servidores da Fepam irem ao local, proibiu-se (legalmente) a catação, iniciando a perseguição: "os guardas não perdoavam se te pegavam sozinho. Quando távamos junto não se metiam, só ameaçavam, mas sozinho eles até batiam. E se um cavalo fugisse e fosse para lá, lá ficava, porque se fosse buscar o problema ia ser maior". Ainda assim, 11 anos depois, em 2009, a catação continuava:

a polêmica existência do aterro Santa Tecla é discutida na justiça desde 2002. De um lado, a prefeitura de Gravataí na busca pelo licenciamento e ampliação. Do outro, ambientalistas e moradores, apoiados pelo Ministério Público, exigem seu fechamento. Já os catadores flagrados no lixão pela reportagem na última terça só querem sobreviver e com isso indiretamente ajudam a manter o depósito em pleno funcionamento (AS MÃOS, 2009, p. 8).

Se a catação não cessou, os catadores foram vítimas de humilhação, ameaça, violência e criminalização. E quando a guarda ficou ostensiva, arriscaram a vida na catação noturna, como relata uma catadora: "quando não deixaram mais catar o lixo, aí começamos a fazer durante a noite e muitas vezes a gente comprou os guardas". Lidar com lixo hospitalar agravava as condições de trabalho, que às vezes se fazia assustadora: "uma vez uma mulher ficou toda contente porque tinha achado um pedaço de carne e foi ver no claro era um seio". Ao local iam tecidos humanos, seringas usadas e todo tipo de objeto cirúrgico contaminado. O próprio supervisor do DMLU admitiu que 30 toneladas/dia de "lixo contaminado dos 31 hospitais da cidade" (RODRIGUES; MAGALHÃES, 2003) eram despejados no local. Desde o tempo do lixão foram décadas de catação em meio a este tipo de "lixo". Em 2004 teria cessado sua deposição oficialmente, mas a fala de uma catadora em 2009 mostra que a catação seguiu:

\footnotetext{
${ }^{11}$ Sobre idas e vindas e disputas legais que marcaram o funcionamento do aterro/lixão, ver Araújo (2017).
} 
o que vou fazer? Não dou para roubar, não foi o que aprendi em casa. Catar lixo não é nobre, mas é digno. Se quiserem tirar a gente como já fizeram com homens armados e tudo mais, podem vir. Enquanto existir o depósito, vamos continuar mantendo nossos pés no valão até chegar ao morro onde os caminhões despejam o lixo da cidade inteira (AS MÃOS, 2009, p. 8).

O relato acima revela a contradição de um Estado que primeiro deixa uma situação limite se tornar fato (criação do lixão) e passe não só a atrair quem vive nas suas margens, mas tirar dele proveito. Como notou Layrargues (2002, p. 12), "catadores e sucateiros atuam como operários terceirizados da indústria da reciclagem, desprovidos de quaisquer benefícios trabalhistas. Essa relação configura a exploração do trabalho pelo capital de modo selvagem e revela uma das engrenagens responsáveis pela concentração de renda no país". Mais tarde, gerada a dependência econômica dos catadores em relação ao lixo, o mesmo poder público atua violentamente, excluindo-os do usufruto de algo que ele próprio criou, mas agora visto como "perigoso" justamente para quem sua ação atraiu, sendo este tratado como "invasor". Poder público que, se antes havia incentivado a ida de lixo hospitalar (rejeito do rejeito), ameaça real à vida de pessoas que com ele lidavam, ao final, se absolve e é absolvido ao dizer "proteger" os catadores negando-lhes a entrada no lixão/aterro e culpabilizando-os por persistir a retirar material do lixo depositado num local criado pela ação do próprio Estado.

Mas o desabafo da catadora, ao alegar que "catar lixo não é nobre, mas é digno" e assim inverter o teor pejorativo que carrega seu ofício, mostra como é possível se reinventar diante da precariedade vivida. Ao contrapor "nobre" x "digno", aponta para a distinção entre riqueza e dignidade, deixando claro que ser rico e ter prestígio (atributos da nobreza) não significa ser digno. Sua persistência (muitas vezes lida por técnicos como "teimosia") mostra que, por trás do ofício de catador, está a força de uma identidade coletiva e o reconhecimento de se ver como parte de um grupo social específico. O que remete ao relato de Lima sobre catadores de Gramacho, para quem, longe do lixo ser só “imundice”, nele havia "coisas de valor": "sua transformação em 
'materiais recicláveis' correspondia não só à valorização dos objetos, mas sua conversão em dinheiro. É em torno dessa bandeira que estes trabalhadores se organizaram para reivindicar sua identidade profissional" (LIMA, 2015, p. 436). Tanto em Gramacho como Santa Tecla inverte-se o senso comum de que viver do lixo retira das pessoas a qualidade de sujeitos. Ao contrário, é desse viver que catadores passam a reivindicar, diante do Estado e da sociedade, direitos, entre eles o de "continuar mantendo os pés no valão" e dele fazer uso.

Fontes oficiais sempre negaram a catação. Para uma fiscal da gerência a prática teria sido abolida logo no início: "teve toda uma organização desses catadores, que foram treinados [...], houve um processo de retirada deles de cima do aterro, porque nossa licença de operação exigia que não tivesse catação em cima dele, isso foi em 2001". Segundo moradores, matérias de jornal (com fotos da catação depois de 2001) e os próprios catadores, a prática seguiu ao menos até 2009. Além disso, relatos fazem crer que a prática nunca tenha cessado, tendo apenas retraído em épocas de maior rigidez e perseguição (como quando Porto Alegre geria o consórcio). Já com o fim do lixão/aterro, agora reduzido a local de passagem de lixo (transbordo), além da redução do volume de material reciclável, em tese, cooperativa e associação não tem mais acesso ao "morro", ao menos segundo seu administrador:

"dois caminhões fazem a coleta seletiva e recebem material da vigilân-
cia sanitária - que traz pra cá alimentos vencidos, carne, coisas apre-
endidas ou retirada dos mercados - e a Secretaria de Ação Social traz
roupas que não servem mais pra venda. É isso, a estação do transbor-
do é praticamente só lixo domiciliar e o lixo seletivo segue diretamen-
te para as unidades de triagem."

Um associado da ARST conta que hoje "diminuiu os associados e quem dependia do lixo pra sobreviver ficou sem renda". Também para outro catador "o fechamento foi ruim pra mim e muitas pessoas que dependiam da reciclagem". De todo modo, a "infernalidade" das opções com a recategorização persistiram: se arriscar à noite no lixo ou perder seu meio de vida. Se no início 
ela trouxe vantagem por aumentar o volume, logo a renda diminuiria com a proibição do trabalho "na flor". Agora, limitados pela gerência, pela associação e o não acesso direto ao lixo, entende-se a saudade nos relatos dos catadores do tempo que "catavam pra si".

\section{Entre chorume, vazamentos e água contaminada}

A contaminação hídrica ocorre tanto pela ação direta de vazamento do chorume como indireta com o mercado informal do lixo. Se a recusa dos garis em recolhê-lo na Vila Tripa leva alguns a jogá-lo no arroio Martins, é comum carros e carroças fazer o mesmo, causando alagamento quando chove. Sobre o chorume - líquido tóxico altamente poluente resultante da decomposição de resíduos orgânicos que deveria ser tratado e não poderia escoar para fora do lixão/aterro -, em 2014 houve um grande vazamento. Segundo a FMMA, 10 mil litros foram para um afluente do rio dos Sinos, contaminando a bacia do Delta do rio Jacuí, cujas águas desembocam no rio Guaíba, que abastece Porto Alegre. Pelo dossiê Aterro Sanitário Santa Tecla, elaborado pela Amalst (ROSA, 2005), o chorume, que jamais foi tratado, era despejado clandestinamente no arroio Martins por um sistema de dutos controlado por válvulas manuais. Ao infiltrar no solo contamina o lençol freático de cuja água faz uso quem vive na Vila Tripa.

Ovazamento e a morte do arroio Martins foram decisivos no fechamento do aterro. De fato, toda comunidade sabia da canalização ilegal, noticiada em 2003: "líquido do lixo contamina arroio com chorume. Vistoria da Fepam determinou retirada em 10 dias dos canos que levam o chorume do aterro Santa Tecla para uma sanga que desemboca no arroio Sapucaia" (MAGALHÃES, 2003, p. 4). Do arroio Martins se retira água para agricultura e criação, tendo já sido local de lazer, banhos e pescarias. Para um integrante da Amalst: "é um crime, o arroio irriga plantações, além de servir como balneário pros moradores" (MAGALHÃES, 2003, p. 4). Já hoje, conforme um morador, "o que se planta não vinga, o arroio Martins está poluído e tudo na volta”. Como o preconceito com a carne de porco, um vizinho diz que o "irmão teve de parar de produzir hortaliça, porque não queriam mais comprar a produção dele. Quem quer comprar algo produzido tão próximo do aterro e irrigado com essa água?”. Água que vem sendo contaminada 
a anos, segundo uma bióloga: "no lixão eram constantes incêndios causados pela combustão do gás metano proveniente de resíduos e explosões resultantes desse acúmulo. No entorno, moradores sofriam com problemas respiratórios e de pele, resultado do não tratamento dos resíduos depositados" (OSELLAME, 2007). Em 2010 a diretora da escola vizinha ao aterro e que recebe alunos da Vila trouxe novamente a questão à público:

as mães que mantêm filhos na escola Humberto de Campos localizado na frente do aterro, cuja emissão de gases são respirados pelas crianças, denunciaram que muitos adoeceram pela ingestão da água servida no estabelecimento de ensino. A diretora da escola recomendou aos alunos e pais que não bebam da água disponível no colégio, pois estaria contaminada. Sua substituta assumiu a direção em maio e conta que leva de casa sua garrafa de água: 'é um problema de saúde pública não levado a sério pelas autoridades. O ambiente ao redor do aterro é malcheiroso: eu que não estava acostumada, sofri muito para permanecer no local' (ALMEIDA, 2009, p. 8).

Uma ex-professora da escola Santa Tecla diz serem "constantes os casos de crianças da Vila que tinham mal-estar na escola, com queixas de dores de cabeça, enjoo e problemas gástricos". Segundo seu secretário, "tivemos uma funcionária que morava na Vila que vivia com diarreia. A diretora desconfiou que a água estava contaminada pelo número elevado de crianças, funcionários e professores com sintoma de diarreia e mandou analisar a água do poço da escola. E foi detectado cólera e um número de coliformes fecais acima do tolerável”.

Já a prefeitura, ao mobilizar o discurso técnico, isenta o aterro/lixão de culpa pela poluição. Apesar de admitir que "tivemos problemas com a comunidade, sobretudo a escola; tivemos muita crítica em função da água estar poluída com coliformes", a encarregada pela fiscalização nega problemas no poço da Humberto de Campos e no aterro/lixão, não havendo relação com a má qualidade da água. Esta viria (como para o ex-diretor do DMLU, que do "topo do aterro" sentia o cheiro) da criação de porcos no entorno: "se pegarmos nossos laudos do aterro, ele não gera coliformes fecais. Porque são oriundos das pocilgas. Tem muito criador de porcos na região, a chuva lixivia e se infiltra. Então 
não é em função do aterro, nós temos os laudos e a comprovação de que não é do aterro". Aqui há uma disputa desigual de evidências: percepção diária $\mathrm{x}$ laudos técnicos. Estes, feitos ou encomendados pela gerência e tendo ao seu lado o saber perito, são difíceis de refutar. O curioso é que, se moradores imputam à poluição da água à montanha de lixo que têm por vizinha, tendo como critério a observação cotidiana, dirigentes do aterro/lixão fazem o mesmo com as "pocilgas da região", visto não haver estudo criterioso para saber sua dimensão e alcance. Ademais, como deposição de lixo e criação de suínos tem efeito parecido (aumento de coliformes e bactérias da cólera), nada impede estarem agindo em sinergia na contaminação da água dos poços.

Mas a disputa pela culpabilidade também é jogada no campo da técnica por quem vive em Santa Tecla. Se a diretora da escola "mandou analisar a água do poço" bebida por crianças e funcionários, a Amalst solicitou um "exame microbiológico para coliformes que constatou a presença de 22 bactérias na água de um de meus poços e 160 bactérias em outro. Essa quantidade não é tolerável ao consumo humano". Em que pese o debate sobre o responsável pela contaminação, todos (técnicos, professores e moradores) parecem concordar que há um problema com a água. Se para quem vive no núcleo do aterro/ lixão este tem de ser enfrentado diariamente, certo é que, para o consórcio do Aterro Sanitário Santa Tecla e para a prefeitura de Gravataí, sua existência trouxe lucro e dividendos políticos.

\section{Poços artesianos, viroses, diarreias e dores de cabeça: fabri- cando a normalidade}

Embora seja visível a importância dos arroios e sua contaminação para quem vive em Santa Tecla, tal unicidade contrasta com a avaliação sobre um tipo específico de água: a dos poços artesianos. Principal fonte d’água no núcleo do aterro/lixão, só um dos 23 entrevistados disse não fazer uso destes. Embora sejam os mais atingidos pela proximidade do lixão/aterro e frequentes as doenças associadas à ingestão da água, para 15 entrevistados os poços são potáveis. Além disso, quem mora neste núcleo no geral não toma maior cuidado ao consumi-la (apenas um disse ferver e colocar cloro e dois compram água). Segundo uma 
moradora, a água seria "boa pra beber" por haver "seres viventes no banhado" que divide seu terreno do lixão. E para a mãe de duas crianças com frequentes problemas de saúde, embora admita que o "chorume não era tratado e sim jogado no arroio Martins e no próprio lixão", o mal-estar dos filhos não teria ligação com a água, pois ela "é de poço, acho que não tem problema".

Como no caso do mau cheiro, aqui é preciso ter em vista que os catadores transitam numa linha tênue entre o impacto do lixão/aterro e ter de tirar dele seu meio de vida. Mesmo vivendo literalmente na pele os problemas, paira a ambivalência entre uma relativa resignação e a denúncia de uma situação limite. Ademais, sua condição social se mistura com o passado afetivo ligado ao lixo, o que não pode ser avaliado a partir de uma leitura moralizante sobre a conduta de cada um ou uma suposta falta de informação. Como visto, muitos têm saudade do tempo do lixão, como nas frases já transcritas "meus filhos foram criados na montanha de lixo e lá brincavam até de escorregador"; "era uma fartura de lixo e a grande maioria das pessoas da Vila sobrevivia dessa forma”. De todo modo, a água de poço ser um problema menor na Vila ajuda a torná-la uma não-questão para a gerência do aterro, o que é reforçado factual e simbolicamente pelas análises da prefeitura, como se vê na constatação desta catadora: "não acho que seja da água, porque a nossa água é boa, é de poço, a prefeitura fez análise”.

Mas não ver a água de beber como questão não significa que seus efeitos não sejam notados. De fato, para um dos autores deste artigo, professora na escola e há nove anos vivendo em Santa Tecla, é visível a frequência com que alunos da Vila adoecem, muitas vezes no mesmo momento. Também é preciso considerar o papel de agentes de saúde na condução dos casos. Para um morador da Vila, "meus filhos têm problema de rinite, diarreia e vômito e os médicos sempre dizem que é virose". Outra conta que "a Vila toda teve surto de diarreia, das crianças aos adultos e até a semana passada ainda tinha gente doente e foi mais de 15 dias assim. E os médicos disseram que é virose". Ao indagar se estes associam a alergia ao aterro/lixão, ela diz que não. Ora, sem uma análise acompanhada que considere onde mora e que tipo de vida leva o paciente (pois o endereço na ficha de atendimento pouco diz sobre as condições insalubres onde vive) e ao não considerar todo passado de contato com o lixo 
e o precário trabalho na catação, o diagnóstico se repete: virose ou problema estomacal. Com isso, tal como problemas respiratórios no núcleo da mineração e o mau cheiro na Vila, passam a fazer parte da rotina, forjando um padrão de normalidade em que diarreia, mal-estar, dor de cabeça e outros problemas de saúde se tornem aceitáveis, corriqueiros e "sem solução".

\section{CONSIDERAÇÕES FINAIS: PRODUZINDO ZONAS (INFERNAIS) E ALTERNATIVAS (DE SACRIFÍCIO)}

Relatos de moradores, técnicos e jornais não deixam dúvida sobre os danos causados pelas minas e aterro/lixão. De fato, neste pequeno distrito do sul do Brasil as duas pontas que unem um derradeiro participante (consumidor/produtor final de mercadoria/lixo) ilustram a banalização da descartabilidade como síntese do mundo moderno. De um lado, a extração mineral que alimenta o sistema capitalista e suas grandes obras; de outro, o que dele resulta: o lixo. No caso da mineradora tem-se como prática a coerção, cooptação, desvio e obstrução ao cumprimento de leis e direitos. Já no aterro/lixão o Estado, na figura do consórcio e prefeitura de Gravataí, se mostra ora omisso, conivente e produtor de injustiças. Ao contrário da mina, onde a chance de emprego é usada como meio de controle, ainda que a reciclagem seja fonte de renda para alguns, o lixão/ aterro operou sem empregar ninguém de Santa Tecla, nem em ocupações auxiliares como segurança, serviços gerais e limpeza, nenhuma exercida por moradores. Mas tanto aterro/lixão como mineradora usam de um discurso que visa atrair a população com a promessa de "benefícios" e "melhorias". Num caso com a alegação de que era preciso "modernizar" o lixão e a gestão do lixo, criando o aterro, noutro pela possível vinda de emprego, renda e obras de infraestrutura. Em ambos a sedução vem do argumento de que minas e lixão/aterro iriam trazer "progresso" e "desenvolvimento". Porém, em troca as pessoas se depararam compulsoriamente com diversos transtornos não anunciados. 
Mas viu-se que há uma diferença de classe operando. Moradores do entorno e núcleo da mineração, não tendo a reprodução social atrelada ao aterro/lixão, denunciam seus danos. Em melhor condição material, seu protagonismo nasce da percepção de perda de algo precioso: a qualidade ambiental que tinha o lugar onde vivem. Já quem vive na Vila e depende do lixo, se não ergueu a bandeira contra o lixão/aterro (cujo fim implicou perda de renda e trabalho), luta por garantir os meios para viver e se contrapor ao que lhe é adverso (sobretudo a proibição da catação). Há também diferença na reação às duas atividades. No núcleo da mineração, apesar do conflito latente, um olhar acurado revela a insatisfação coletiva com as minas, com moradores absorvendo todo dano ambiental. Expressando sua contrariedade e sufocada por alternativas infernais, a resistência tem sido individual e a crítica se dando de modo pontual. Já o confronto em torno do aterro/lixão foi essencial para parar a deposição de lixo, sendo hoje apenas local de transbordo de resíduos que agora vão para a cidade de Minas do Leão.

Mas "enquanto houver áreas de menor resistência, toda decisão que restringe o dano" de atividades danosas pode ser seguida pela sua transferência a outro local também fragilizado (ACSELRAD; BEZERRA, 2010, p. 206), com a vitória de uma localidade consistindo em perda futura a outra. É o caso de Minas do Leão, há setenta anos sofrendo com as minas de carvão e hoje destino do lixo metropolitano. Isto é, os danos não cessaram, só se deslocaram, levando para lá a invisibilidade garantida das crateras abandonadas pela retirada do carvão e os impactos já habituais em Santa Tecla. Seja pedra ou carvão, se a esta fica o amargo usufruto da promessa do progresso, a Minas do Leão resta a confirmação de zona infernal cuja alternativa é o sacrifício de sua população, reafirmando um movimento em que um dos bens mais preciosos na sociedade capitalista (o minério) se junta ao que esta busca de todo modo rejeitar (o lixo).

Voltando a Santa Tecla, lá o conflito e a disputa pela apropriação, significado e uso deste território e seus recursos oscila entre lugar para viver e/ ou trabalhar e local de onde se retira riqueza (desigualmente partilhada) e despeja-se lixo (injustamente socializado). A começar por proprietários, 
gestores e políticos locais, que, não vivendo na localidade, não são afetados. Também para as prefeituras do consórcio o aterro/lixão foi positivo ao resolver seu problema de deposição de lixo. Talvez por isso seus prefeitos se dedicarem tanto a mantê-lo aberto por anos mesmo esgotada sua capacidade. Mas a despeito de todo valor recebido pela prefeitura de Gravataí e do benefício às demais, pouco retornou para Santa Tecla e, em especial, à Vila Tripa. Ao contrário, ao invés de fechar o antigo lixão e pensar alternativas de renda para quem dele dependia, moradores ganharam um reciclado aterro sanitário operando de modo irregular e recebendo lixo tóxico. Já os catadores e quem trabalha com reciclagem, primeiro lhes foi exigido dividir o pouco (os porcos) que tinham barganhando com guardas do aterro e, depois de totalmente barrados de nele entrar, foram alvo do exercício da violência institucional.

Exceto por esta última, nenhuma política pública foi pensada para este público já vulnerabilizado. Entre as diversas opções estavam: recuperar estradas e sinalização; controlar o fluxo de caminhões; executar projetos garantindo outras rendas a moradores; descontaminar rios, arroios e poços; recuperar remanescentes da Mata Atlântica; viabilizar a regularização fundiária da Vila Tripa; assegurar o monitoramento efetivo (e honesto) do chorume; investir no turismo rural. Mas tais metas não eram prioridade para mineradora, prefeitura de Gravataí e consórcio. Destes, veio só dissimulação, descaso e desrespeito às leis ambientais.

\section{REFERÊNCIAS BIBLIOGRÁFICAS}

1. ACSELRAD, Henri. Práticas espaciais e o campo dos conflitos ambientais. In: ACSELRAD, Henri (org.). Conflitos ambientais no Brasil. Rio de Janeiro: Relume:Dumará, 2004.

2. ACSERALD, Henri. Desregulação, deslocalização e conflito ambiental: considerações sobre o controle das demandas sociais. In: ALMEIDA, Alfredo Wagner Berno de (org.). Capitalismo globalizado e recursos naturais territoriais: fronteiras da acumulação no Brasil contemporâneo. Rio de Janeiro: Lamparina, 2010. 
3. ACSELRAD, Henri; BEZERRA, Gustavo. Inserção econômica internacional e "resolução negociada" de conflitos ambientais na América Latina. In: ZHOURI, Andrea; LASCHEFSKI, Klemens (org.). Desenvolvimento e conflitos ambientais. Belo Horizonte: Editora UFMG, 2010. p. 35-62.

4. ACSELRAD, Henri; MELLO, Cecília; BEZERRA; Gustavo. das Neves. O que é justiça ambiental. Rio de Janeiro: Garamond, 2009.

5. AS MÃOS que reviram o lixo. Correio de Gravataí, Gravataí: ano 25, n. 3533, p. 8-9, ago. 2009.

6. ALMEIDA, Elen. Garimpando lixo. Correio de Gravataí. Gravataí, ano 25 n. 3532, p. 8, ago. 2009.

7. ARAÚJO, Lair. Aterro/Lixão, mineração e moradores sacrificados: conflito ambiental e "alternativas infernais" em Santa Tecla. 2017. Dissertação (Mestrado em Desenvolvimento Rural) - Programa de Pós-Graduação em Desenvolvimento Rural Universidade Federal do Rio Grande do Sul. Porto Alegre: 2017.

8. GERHARDT, Cleyton. Grandes projetos de desenvolvimento e a produção estrutural da insustentável desigualdade ambiental. Ruris. Campinas: v. 8, n. 2 set. 2014 .

9. INSTITUTO BRASILEIRO DE GEOGRAFIA E ESTATÍSTICA. Censo 2010. Rio de Janeiro, 2012.

10. LAYRARGUES, Philippe. O cinismo da reciclagem: o significado ideológico da reciclagem da lata de alumínio e suas implicações para a educação ambiental. In: LOUREIRO, Carlos.; LAYRARGUES, Philippe.; CASTRO, Ronaldo (org.) Educação ambiental: repensando o espaço da cidadania. São Paulo: Cortez, 2002.

11. LIMA, Maria Raquel. O Avesso do Lixo: materialidade, valor e visibilidade. 2015. Tese (Doutorado em Antropologia Cultural) - Programa de Pós-Graduação em Sociologia e Antropologia, Universidade Federal do Rio de Janeiro. Rio de Janeiro: 2015.

12. MAGALHÃES, Carlos. Líquido de lixo ameaça arroio em Gravataí. Diário Gaúcho. Porto Alegre, ano 4, n. 993, p. 4, 4 jun. 2003.

13. MELLO, Cecília. Contra as "alternativas infernais". Revista Contra-Corrente. Brasília: Rede Brasil sobre Instituições Financeiras Multinacionais, n. 1, p. 28-30, nov. 2009.

14. OSELLAME, Luís. Parlamentares visitam aterro sanitário de Gravataí. Agência de Notícias da Assembleia Legislativa do Rio Grande do Sul. Porto Alegre, 19 nov. 2007. Disponível em: http://bit.ly/2TdWdCu. Acesso em: 06 jun. 2019.15. RODRIGUES, Eduardo; MAGALHÃES, Carlos. Lixo hospitalar ameaça saúde pública. Diário Gaúcho. Porto Alegre: ano 4, n. 987, p. 4, 18 jun. 2003. 
15. ROSA, Carlos. Dossiê Aterro Sanitário Santa Tecla. Porto Alegre, 2005. Mimeografado.

16. TORRES, Eduardo. Aterro opera sem licença e não dura um ano diz Fepam. Correio de Gravataí. Gravataí: ano 25, n. 3.123, p. 9, 28 mar. 2008.

17. VIEGAS, Rodrigo Nuñez. Desigualdade ambiental e "Zonas de Sacrifício”. Rio de Janeiro: FASE: IPPUR, 2006 Disponível em: http://bit.ly/39WrHmp. Acesso em: 11 nov. 2018. 